Primljen / Received: 19.6.2016. Ispravljen / Corrected: 24.2.2017.

Prihvaćen / Accepted: 10.4.2017. Dostupno online / Available online: 10.6.2017.

\section{Shear connection with groups of headed studs}

Authors:

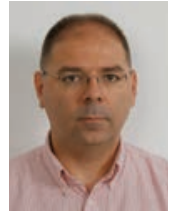

${ }^{1}$ Asisst.Prof. Milan Spremić, PhD. CE spremic@grf.bg.ac.rs

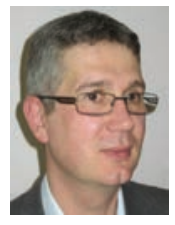

${ }^{1}$ Prof. Zlatko Marković, PhD. CE zlatko@imk.grf.bg.ac.rs

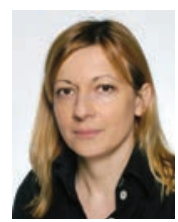

${ }^{1}$ Asisst.Prof. Jelena Dobrič, PhD. CE jelena@imk.grf.bg.ac.rs

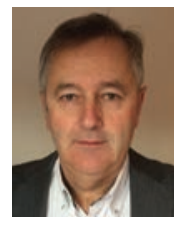

2Prof. Milan Veljković, PhD. CE m.veljkovic@tudelft.nl

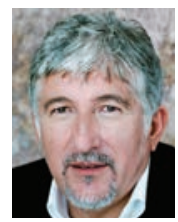

${ }^{1}$ Prof. Dragan Budevac, PhD. CE budjevac@grf.bg.ac.rs

'University of Belgrad, Faculty of Civil Eng. ${ }^{2}$ Technical University of Delft, Faculty of Civil Engineering and Geodesy
Subject review

Milan Spremić, Zlatko Marković, Jelena Dobrić, Milan Veljković, Dragan Budevac

\section{Shear connection with groups of headed studs}

The behaviour and characteristics of the elements of prefabricated composite steel and concrete structures are determined by behaviour of the longitudinal shear connection. Headed studs in groups are most frequently used for forming longitudinal shear connection of prefabricated composite beams. The results of experimental research and advanced numerical models of shear connections, obtained using groups of headed studs, are presented in the paper. When headed studs are arranged in groups, it is recommended to use the headed studs with the height greater than the $4 \mathrm{~d}$ height prescribed by the Eurocode.

Key words:

shear connection, groups of studs, prefabricated composite beams

Pregledni rad

Milan Spremić, Zlatko Marković, Jelena Dobrić, Milan Veljković, Dragan Budevac

\section{Posmični spoj ostvaren grupama moždanika s glavom}

Ponašanje i karakteristike predgotovljenih spregnutih elemenata konstrukcija od čelika i betona određeni su ponašanjem uzdužnog posmičnog spoja. Grupe moždanika s glavom najčešće se koriste za formiranje uzdužnog posmičnog spoja predgotovljenih spregnutih nosača. U radu su prikazani rezultati eksperimentalnih istraživanja i naprednih numeričkih modela posmičnih spojeva, koji su ostvareni grupama moždanika s glavom. Kada se moždanici izvode u grupama, preporuka je da se koriste veće visine od 4d koja je propisana europskom normom.

Ključne riječi:

posmični spoj, grupe moždanika, predgotovljeni spregnuti nosači

Übersichtsarbeit

Milan Spremić, Zlatko Marković, Jelena Dobrić, Milan Veljković, Dragan Budevac

\section{Scherverbindungen realisiert durch gruppierte Kopfdübel}

Das Verhalten und die Eigenschaften vorgefertigter Verbundelemente für Konstruktionen aus Stahl und Beton werden durch das Verhalten der Scherverbindungen in Längsrichtung bestimmt. Meistens werden gruppierte Kopfdübel angewandt, um diese Verbindungen zu realisieren. In dieser Arbeit werden die Resultate experimenteller Untersuchungen und fortschrittlicher numerischer Modelle von Scherverbindungen, die durch gruppierte Kopfdübel realisiert werden, dargestellt. Bei einer Anordnung der Dübel in Gruppen, ist es empfehlenswert größere Dübelhöhen als die gemäß europäischer Norm vorgeschriebene Mindesthöhe von 4d anzusetzen.

Schlüsselwörter:

Scherverbindung, gruppierte Dübel, vorgefertigte Verbundträger 


\section{Introduction}

The industrialized building construction has resulted in a considerable presence of prefabricated buildings. This trend is particularly visible in composite floor structures. The paper presents experimental and theoretical results of research focusing on longitudinal shear connections with grouped headed studs. Such design of shear connections of prefabricated composite structures is most frequently applied in the construction of prefabricated composite bridges (see Figure 1).

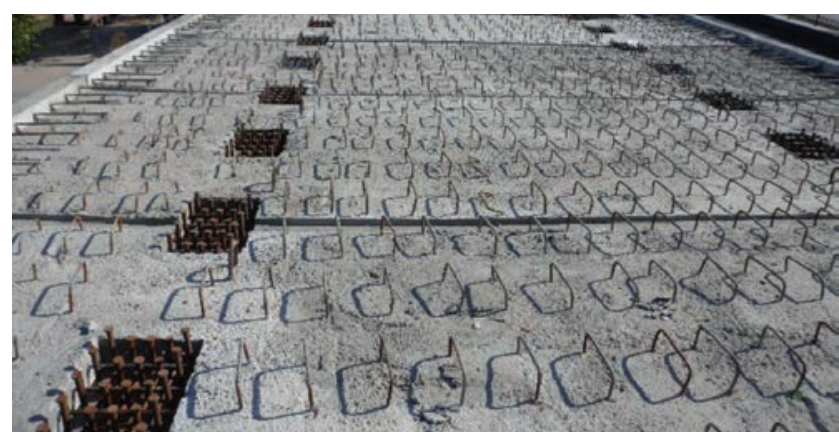

Figure 1. Application of a group of headed studs in bridge construction

A shear connection formed with groups of headed studs is a discontinuous connection. Headed studs in groups are arranged at the openings of prefabricated concrete slabs. After assembly of the slabs, the infill concrete is cast in the openings. When grouping the headed studs, the goal is to obtain minimum group dimensions, the purpose being to reduce the size of the openings in the prefabricated RC slabs. In practical application, it is important to undertake experimental and theoretical analyses of the shear resistance and behaviour of the longitudinal connection with groups of headed studs arranged at smaller intervals between the studs in the direction of shear force, as compared to the values prescribed in the corresponding design code.

The shear connection of typical composite floor beams in buildings is analysed in the paper. The analysed headed studs in group arrangement are spaced at smaller stud intervals in the direction of the shear force, compared to the minimum prescribed value of $5 d$ ( $d$ - headed stud diameter). Perpendicularly to the direction of the shear force, the minimum proscribed distance between the headed studs in a solid concrete slab is $2.5 d$, which is slightly higher than the minimum distance which is around $2.1 \mathrm{~d}$.

In addition to restricting slipping between concrete and structural steel, mutual separation of various components of cross-section must be prevented in order to realize composite action of various parts of cross-section of a composite element. The way in which longitudinal shear force is transferred between the structural steel and concrete slab is one of the main structural properties of a composite element. For this reason, it is of a particular importance to analyse behaviour of shear connections.

\subsection{Previous research}

Standard specimens with nine headed studs in a $3 \times 3$ arrangement have been examined in previous experimental studies of shear connections in prefabricated beams with grouped headed studs. The most important studies on shear connections involving groups of headed studs were presented by: Okada et al. [1], Shim C.S. [2], Dongyan et al. [3], Guezouli et al. [4], Chen Xu et al. [5]. Out of all these studies, only the experimental research performed by Shim C.S. [2] examined shear resistance of headed studs in group arrangement that is influenced by the distance between studs, which was smaller than the standardly prescribed minimum distance. Eurocode 4, part 2 [6] for composite bridges, permits implementation of grouped headed studs in shear connections and prescribes that the following factors must be considered: local stress in concrete, non-uniform transfer of forces between two parts of a cross section, and potential high values of slipping in the longitudinal shear connection. There are no explicit recommendations for the design of shear connectors with groups of headed studs in current issues of relevant codes. Out of the above mentioned studies, only Okada et al. [1] and Shim C.S. et al. [2] provide some recommendations for the design of characteristic longitudinal shear resistance of connections, realized by groups of headed studs.

\section{Experimental research}

The experimental research included six series of standard pushout specimens, in accordance with the Annex B of Eurocode
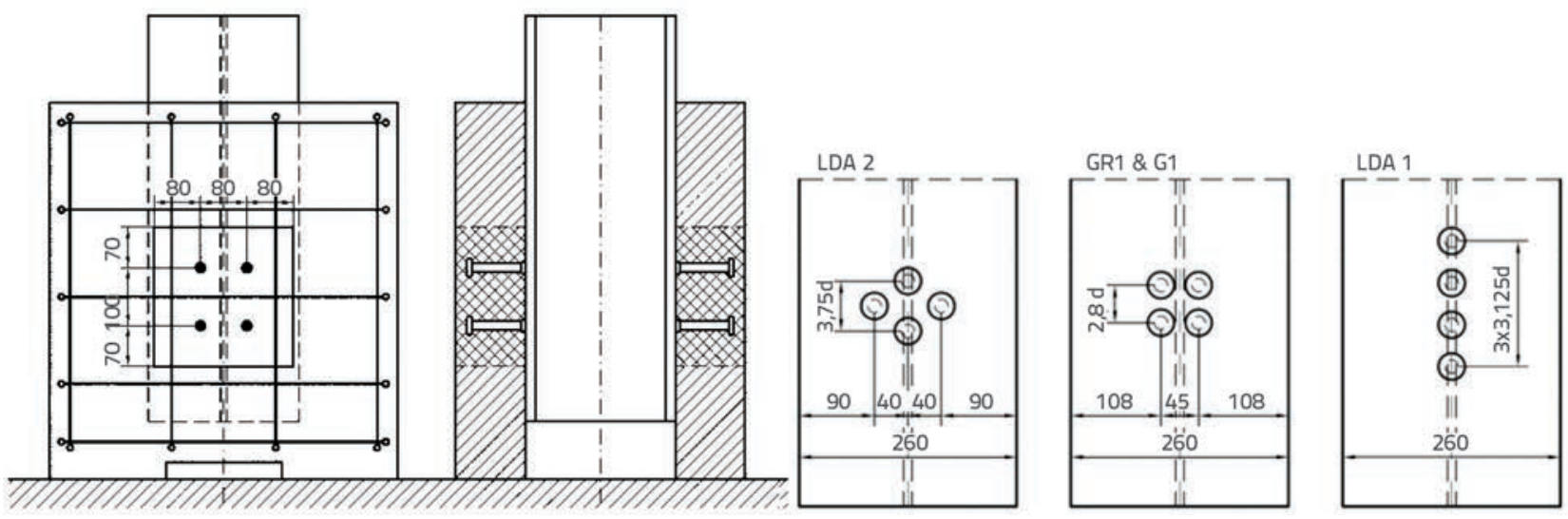

Figure 2. Standard specimens and tested groups of headed studs 
4 [7]. Shear connectors were constructed with four headed studs $16 \mathrm{~mm}$ in diameter. The connection was realized with the standard arrangement of headed studs, according to Eurocode 4 [8] (series ST). Besides, the specimen series G1, GR1, LDA1 and LDA2, with grouped headed studs and reduced distance between the studs, were tested. The tested series are shown in Figure 2.

Every specimen was formed of the steel profile HEB 260 and two prefabricated slabs $12 \mathrm{~cm}$ in thickness. The slabs were reinforced by class $B 500$ reinforcement $10 \mathrm{~mm}$ in diameter, according to Eurocode 4, Annex B [8]. The specimens were filled with concrete in the laboratory, as shown in Figure 3. After the RC slab was placed over the structural steel, the openings in concrete slab were grouted, first one side and, three days later, the other side of the specimen, see Figure 3.

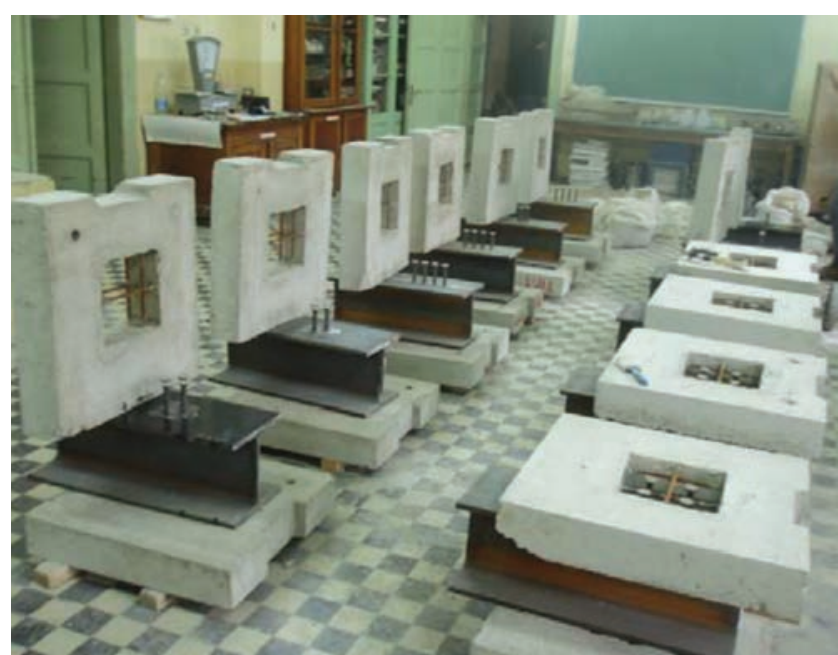

Figure 3. Specimen assembly in laboratory

The infill concrete with the largest nominal aggregate size of $16.0 \mathrm{~mm}$ was used. When designing the concrete mix, one of the goals was to obtain a concrete with the smallest possible shrinkage. Using admixtures for concrete shrinkage reduction, the shrinkage was $20 \%$ lower than the calculated values obtained according to Eurocode 2 [9]. Comparison of the concrete shrinkage-time curve with the design curve according to [9] is presented in Figure 4. Shrinkage was measured on control specimens in laboratory, with the controlled air temperature and humidity values, see Figure 5 . The air temperature and relative humidity values were monitored during the testing. The measured temperature and relative humidity values were within the range of $20-25^{\circ} \mathrm{C}$ and $23 \pm 2 \%$, respectively.

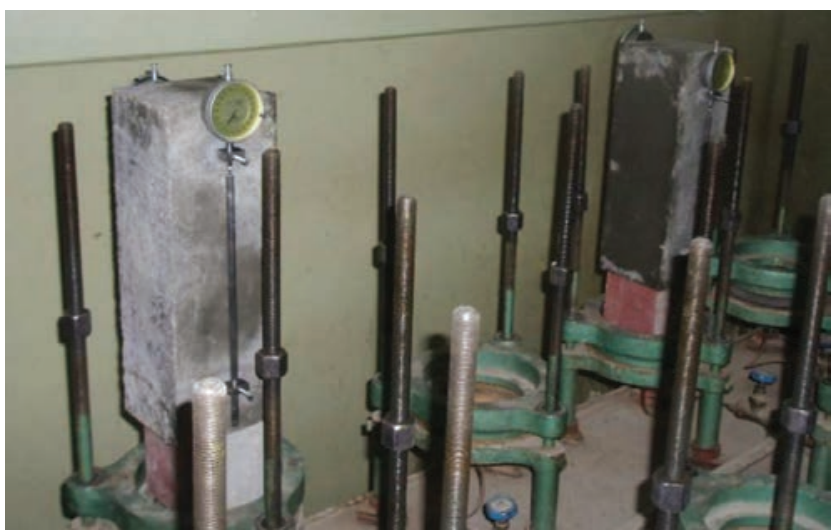

Figure 5. Measurement of concrete shrinkage

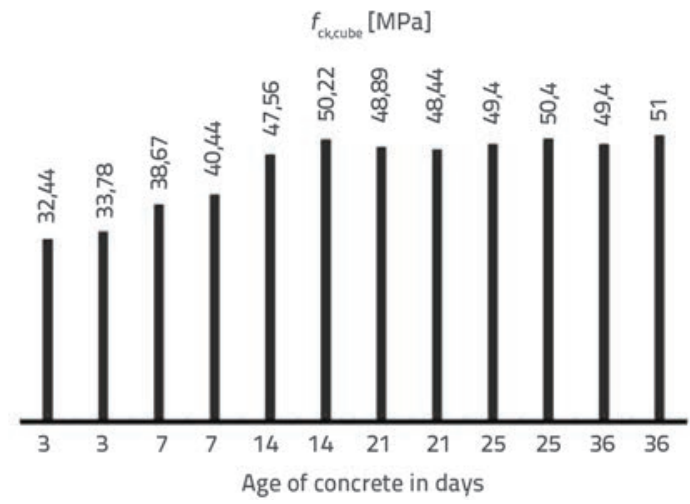

Figure 6. Increase in concrete strength

The steel element surface was coated with oil prior to concreting, in order to eliminate concrete adhesion. The RC slab areas that were in direct contact with fresh concrete were treated by the coating for contact between the old and new concrete. Three days after one side

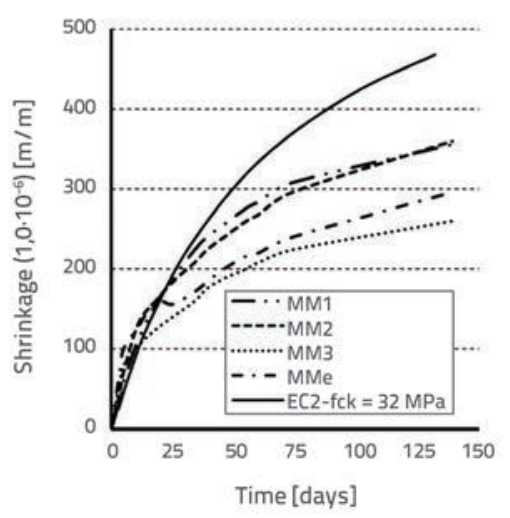

Figure 4. Concrete shrinkage diagrams

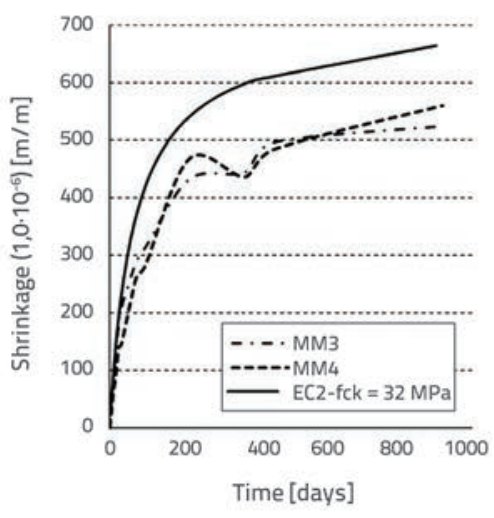

of the specimen was concreted, specimens were turned over and the other specimen side was concreted. Specimens were tested 21 days after concreting of the second side, i.e. 24 days after concreting of the first side of the specimen. The relation between the concrete strength and concrete age is shown on the diagram given in Figure 6 . Based on the results from diagram shown in Figure 6, it can be concluded that there is no difference in compressive strength between infill concretes. Therefore, the distinctions between the concrete strengths after first 14 days are negligible. 
The stress-strain material curves were defined for structural steel material and headed stud material using the standard tensile test. Coupons of reinforcement bars used in construction of RC slabs were also tested. The tensile coupon test results for headed stud material are presented in Figure 9. Detailed material testing results are provided in [7].

The specimen testing was performed in two phases in accordance with EN1994-1-1, Annex B. The specimens were first loaded 25 times up to $40 \%$ of the expected shear resistance (approximately $270 \mathrm{kN}$ ), after which they were unloaded to $5 \%$ of the expected shear resistance (approximately $32 \mathrm{kN}$ ). After "training", the specimens were loaded to failure, so that the last loading cycle had to last no less than 15 minutes. During the test, it was important that the specimen failure occurs 20-25 minutes after the start of the last cycle of load application.

The load cell with the range of up to $1000 \mathrm{kN}$ and the hydraulic press acquisition unit were used for measuring the force intensity. The slip in shear connection was measured using two LVDT sensors $(s 1, s 2)$ per side of specimens, see Figure 7. The separation in shear connection between the concrete slab and steel section, and separation of concrete slabs, were continuously monitored at two points using LVDT sensors u1, $u 2$, and u3. The set-up for shear connector testing is shown in Figure 7.

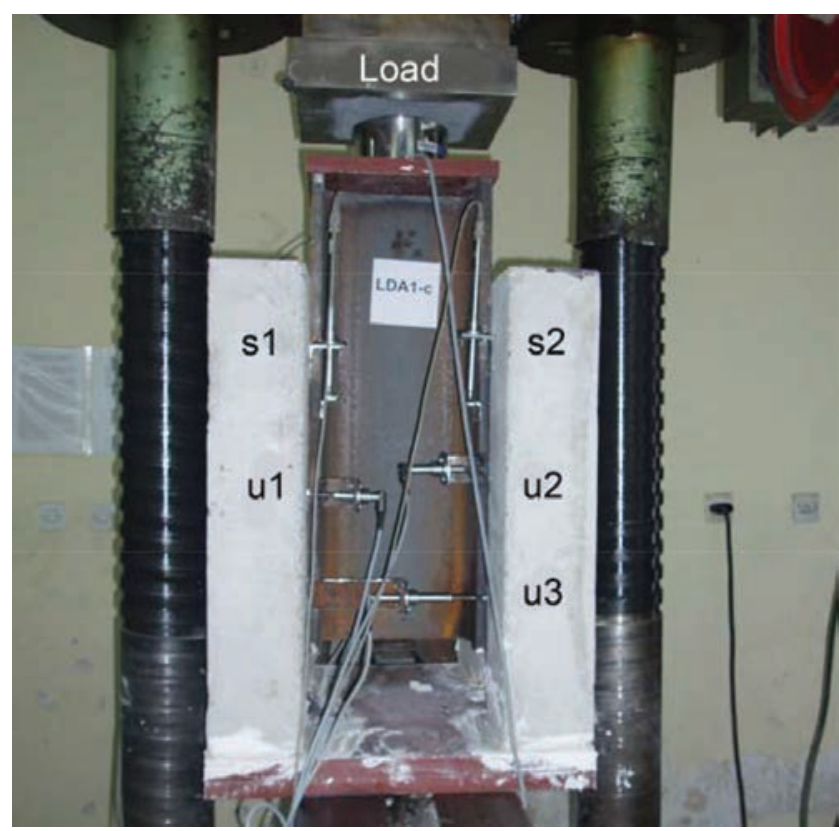

Figure 7. Specimen testing

\subsection{Experimental results}

Experimental results obtained by push-out testing are thoroughly analysed in the study conducted by Spremic et al. [10]. Essential findings from the above study are presented in this paper. Average load - slip diagrams are presented in Figure 8. Specimens G1 and GR1 were prepared with the same arrangement of headed studs, but with different types of prefabricated slabs. Specimens
GR1 had the reinforcement bars immediately in front of the headed studs, which is at the same time used for connecting the prefabricated slab and the infill concrete, while in the case of G1 specimens, the reinforcement bars do not exist [10]. The same results for the ultimate shear resistance and the ductility at ultimate load were obtained for specimens G1 and GR1. In this way, it was confirmed that the reinforcement immediately in front of a group of studs has no influence on the shear resistance and ductility of the group. The same result was registered in the study made by a group of authors [11].

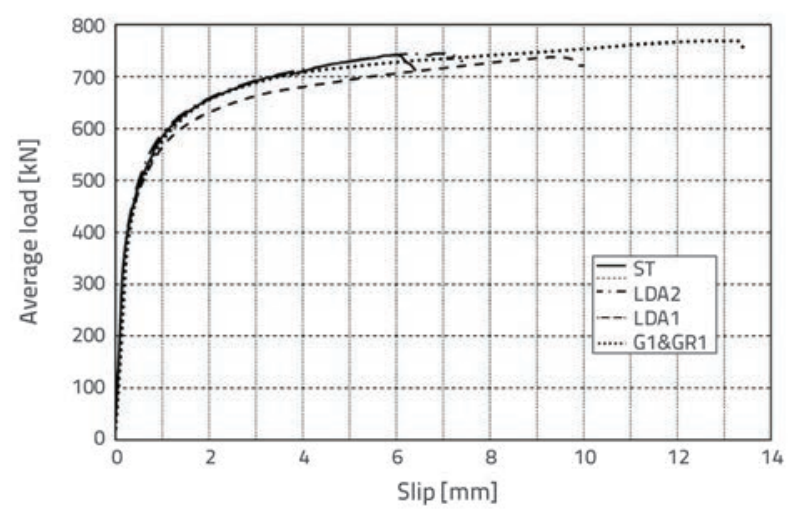

Figure 8. Average load-slip curves for tested groups of studs

The ratios of the characteristic value of shear resistance $P_{R k, E x p}$ obtained in experimental test to the characteristic shear resistance $\mathrm{P}_{\mathrm{Rk}, \mathrm{EC} 4}$ calculated according to Eurocode 4, are summarized in Table 1. Experimental mechanical properties of headed studs and concrete were used for the calculation of characteristic shear resistance $\mathrm{P}_{\mathrm{Rk}, \mathrm{EC} 4 \text {, }}$ as also shown in Table 1. Only in the case of the LDA1 group, the characteristic shear resistance of tested specimens was by $6 \%$ lower compared to the characteristic design value.

Table 1. Test results

\begin{tabular}{|c|c|c|c|}
\hline $\begin{array}{c}\text { Specimens } \\
\text { (distance) }\end{array}$ & $\begin{array}{c}\mathbf{f}_{\mathrm{ck}} \\
{[\mathrm{MPa}]}\end{array}$ & $\begin{array}{c}\mathbf{E}_{\mathrm{cm}} \\
{[\mathrm{MPa}]}\end{array}$ & $\mathbf{P}_{\mathrm{Rk}, \mathrm{Exp}} / \mathbf{P}_{\mathrm{Rk}, \mathrm{EC} 4}$ \\
\hline $\mathrm{ST}(6,25 d)$ & 34 & 36000 & 0.99 \\
\hline $\mathrm{GR} 1(2,8 d)$ & 32 & 34000 & 1.08 \\
\hline $\mathrm{G} 1(2,8 d)$ & 32 & 34000 & 1.08 \\
\hline $\mathrm{LDA} 1(3,1 d)$ & 34 & 36000 & 0.94 \\
\hline $\mathrm{LDA} 2(3,75 d)$ & 34 & 36000 & 1.03 \\
\hline
\end{tabular}

The behaviour of all tested specimens was ductile, as the measured slip values at failure were higher than $6,0 \mathrm{~mm}$, which is the minimum limit according to Eurocode 4 for a connection to be considered ductile (see diagrams in Figure 8). The failure of connection at ultimate shear load of specimens occurred due to the headed stud shear failure. The specimens of the series $\mathrm{G} 1$ 
and GR1 are characterized by the combined failure mode. In the case of specimens G1 and GR1, the slip values at ultimate load were up to $80 \%$ higher with respect to the standard arrangement of headed studs (series ST), and so it can be concluded that the combined failure mode occurred.

\section{Numerical analysis}

The FEM analysis with ABAQUS-Explicit software, and with non-uniform mass scaling during calculation, was conducted for the simulation and verification of the presented experimental research. Two planes of symmetry of the specimens were used, and so only one quarter of the sample was modelled. The general contact option, with hard contact for normal behaviour, and penalty with friction coefficient of 0.24 for tangent behaviour, was adopted for all contact conditions between individual parts of the FE model. The RC slab support perpendicular to load direction was defined as elastic support. The support stiffness varied between 20000 $\mathrm{N} / \mathrm{mm}$ and $24000 \mathrm{~N} / \mathrm{mm}$. The support stiffness value of $21000 \mathrm{~N} / \mathrm{mm}$ was adopted in the process of model calibration. The load-slip curves obtained from push out test were used for calibration of FE models. The defined material models used in the calculation were calibrated using experimental results of material coupons: steel and headed studs. The models for simulation of material damage, "ductile damage" and "shear damage", were also used for the headed stud material. The damage variable value of 1.0 corresponds to the equivalent plastic displacement, and amounts to $0.204 \mathrm{~mm}$. Displacement at failure of $0.4 \mathrm{~mm}$ was adopted for shear damage of headed studs. The damage variable to equivalent plastic displacement curves are described in papers published by Spremic et al. [12] and Spremic [7].

The stress-strain curve defined in Eurocode 2 for concrete C35/45 was used for the part of the stress-strain curve up to the strain of $\varepsilon_{\mathrm{cu} 1}=3.5$. In the strain region $\varepsilon_{\mathrm{c}}>3.5$, the stressstrain curve was analytically described using the Chinese code GB50010-2002 [14] with some modifications according to Chang Xu et al. [4] and Pavlović et al. [13].

Cracks and damage in the concrete part of cross-section were determined using the "concrete damage plasticity" model. The damage variable for compression is equal to zero in the stress domain up to the inelastic concrete strain of $0.0014 \%$. Furthermore, the damage variable amounts to 0.995 for the inelastic strain of $0.1 \%$. The time dependent characteristics, shrinkage and creep of concrete, are not included in the concrete material model. The shrinkage of concrete is minimized with an adequate mix of infill concrete used in push - out tests. The duration of push-out tests has no influence on the creep of concrete.

The material models are described in detail in [13]. Figure 9. presents the stress-strain diagram for the headed studs material obtained through experiments and via the calibrated FEM model.

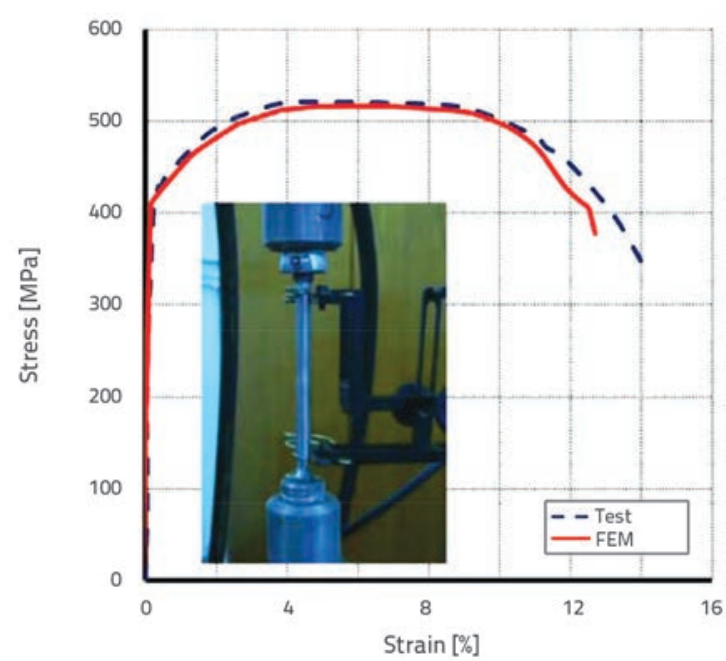

Figure 9. Stress-strain curves for studs, tension test and FE material model

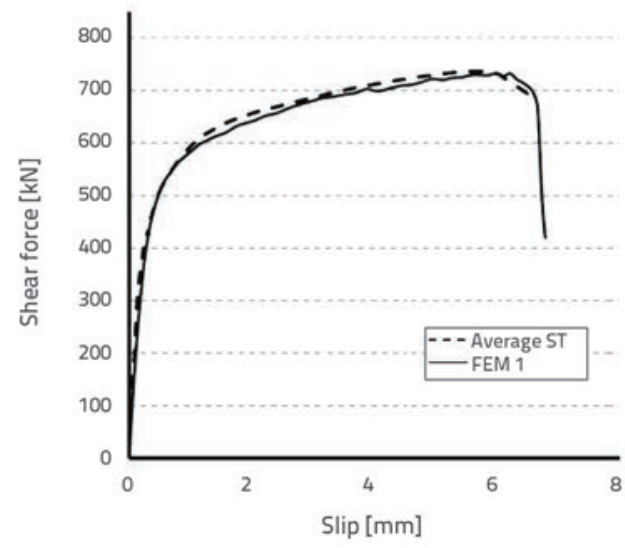

Figure 10. Load-slip curves, test and FEM model values

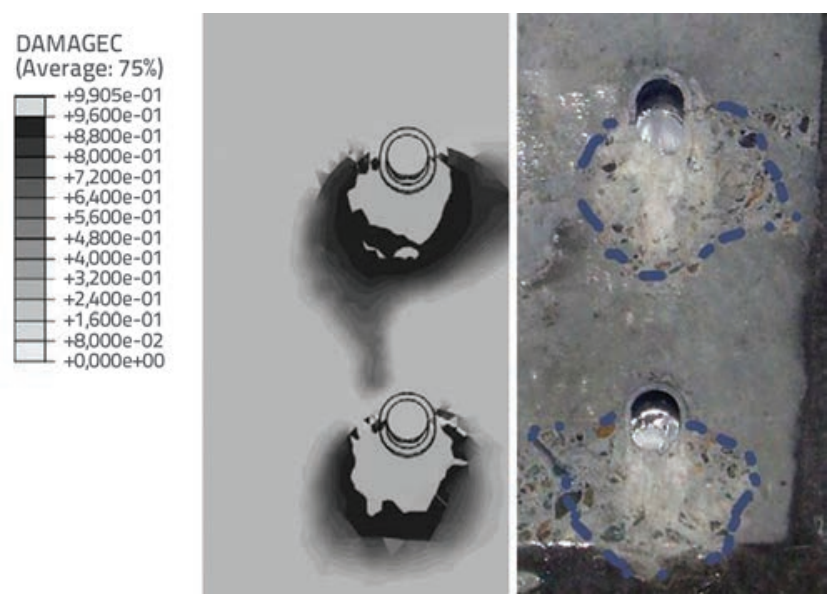

Figure 11. Concrete damage zone, FEM and test values

The results in form of load-slip curves of a calibrated FEM model are presented in Figure 10 along with experimental results. The displayed diagrams confirm a good correspondence of results. In addition, the concrete damage zones immediately 
in front of the headed studs in a RC slab after testing were compared with the maximum values of damage parameters from the FEM model, see Figure 11. Here also a good match was obtained between damaged surfaces of RC slabs.

\section{Behaviour of shear connection}

Headed studs, as the most frequently applied shear connection devices, and their properties, are included in all actual codes. According to EN1994, the headed stud shear resistance is defined as a function of the headed stud diameter, properties of headed stud material, and compression strength of concrete. Diagrams defining a characteristic shear resistance value of headed studs $16 \mathrm{~mm}$ in diameter, as related to characteristic compressive strengths of concrete, are presented in Figure 12. These resistance values were calculated according to $[8$, 15-17]. The shear resistances of headed studs, both in terms of concrete failure or headed stud shear failure, are the same for the concrete compressive strength of approximately $35 \mathrm{MPa}$. Concrete failure is relevant failure mode for lower concrete strength values, while headed stud shear failure is relevant for higher concrete strength values, see Figure 12.

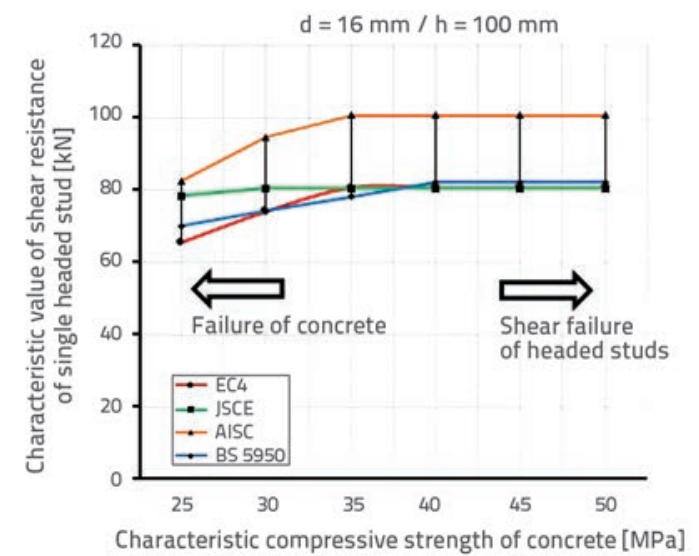

Figure 12. Shear resistance of headed studs

By grouping the headed studs and by reducing distance between headed studs, the local stresses in concrete become higher as compared to the stresses in concrete in case of standard arrangement of headed studs. However, as shown in diagrams presented in Figure 12, the shear failure of headed
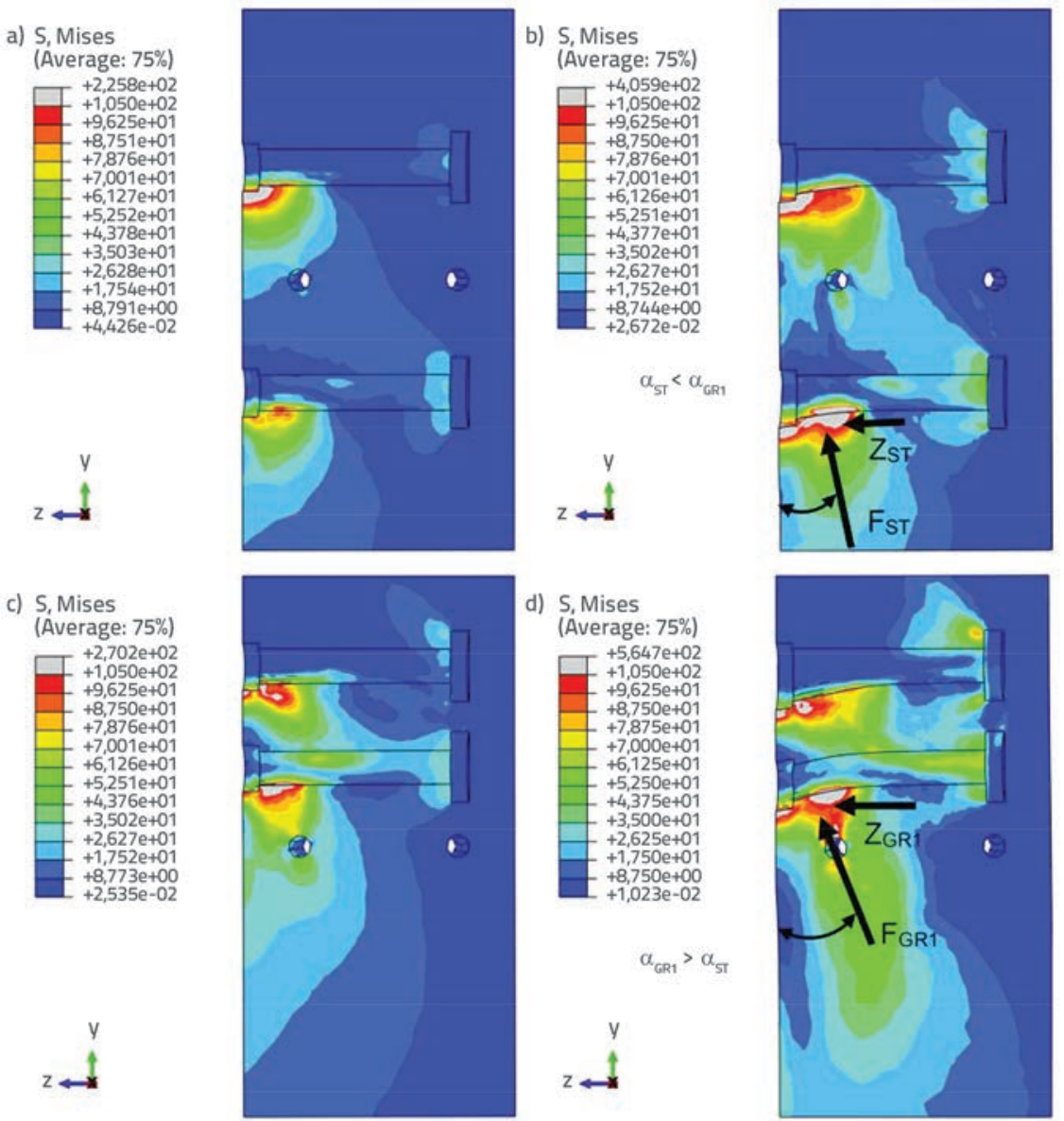

Figure 13. Stress in concrete slab : a) ST-SLS load; b) ST - $90 \%$ ULS load; c) GR1 - SLS load; d) GR1 - $90 \%$ ULS load

studs is the only relevant failure mode for higher compressive strength values of infill concrete. It can be concluded that distances between headed studs can be reduced if concretes with high values of compressive strength are used. Regarding the construction method, it is completely justifiable and economically acceptable that concretes presenting higher compressive strength are used for shear connection.

Figure 13 shows stress distribution in concrete for standard arrangement of headed studs ST, and for the group of headed studs GR1. The presented stress values are for the load values corresponding to the SLS and to $90 \%$ of the ULS load. The stresses in concrete are higher for the group GR1 as compared to the ST group, see Figure 13. Stresses in concrete in front of the group of headed studs GR 1 are by $17 \%$, i.e. $36 \%$ higher than the stress in concrete in front of the headed studs of specimens ST, for $70 \%$ and $90 \%$ of the ULS load, respectively, see Figure 14. In addition, it is clearly visible that top layers of concrete are activated, starting from the contact surface between the steel and concrete, in the case of the headed studs belonging to group GR1. This results in the change of the resultant load position in the contact plane of headed studs and concrete, in case of GR1 group, see Figures 13 and 14. At higher stress values, 

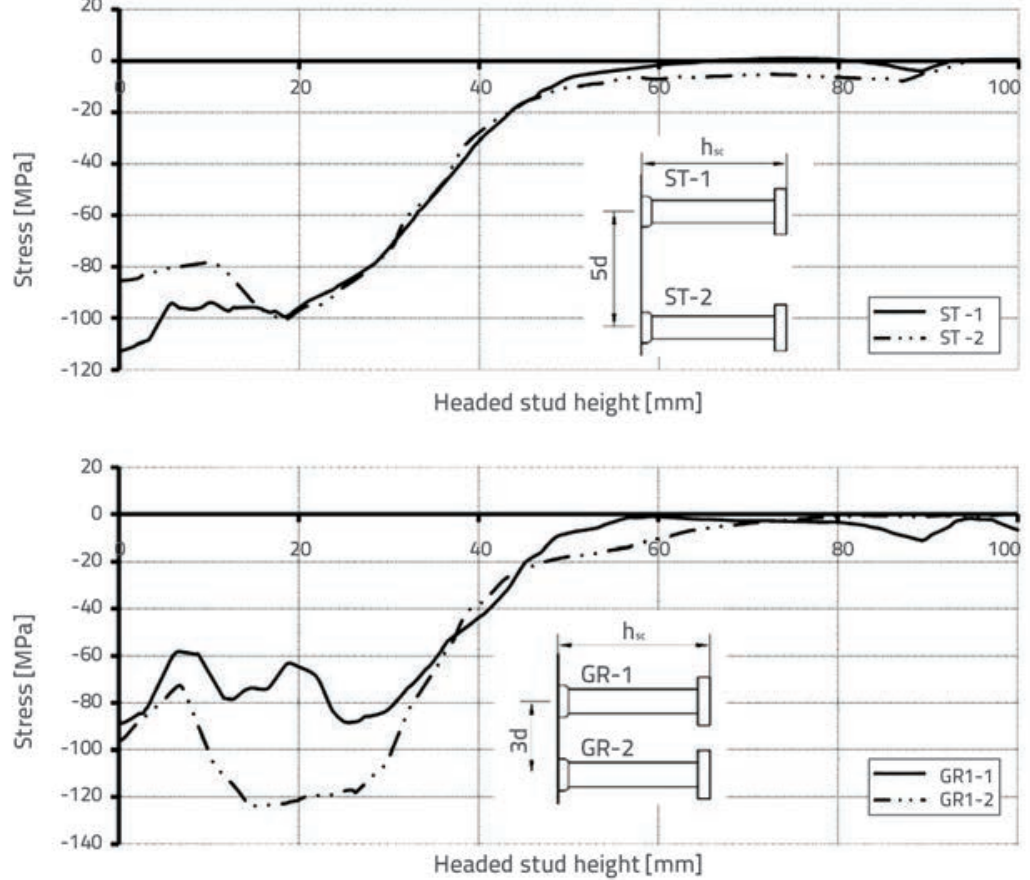

Figure 14. Stress in concrete slab

the concrete next to the root of the headed studs is severely damaged, which results in an increase of the angle between the resultant force and contact area, $\alpha_{\mathrm{GR} 1}>\alpha_{\mathrm{ST}}$. A higher tensile stress in headed studs occurs due to the change of the resultant force angle, see Figure 13. The same conclusion can also be made by comparing stress values in the concrete zone around the stud heads, see Figure 13.
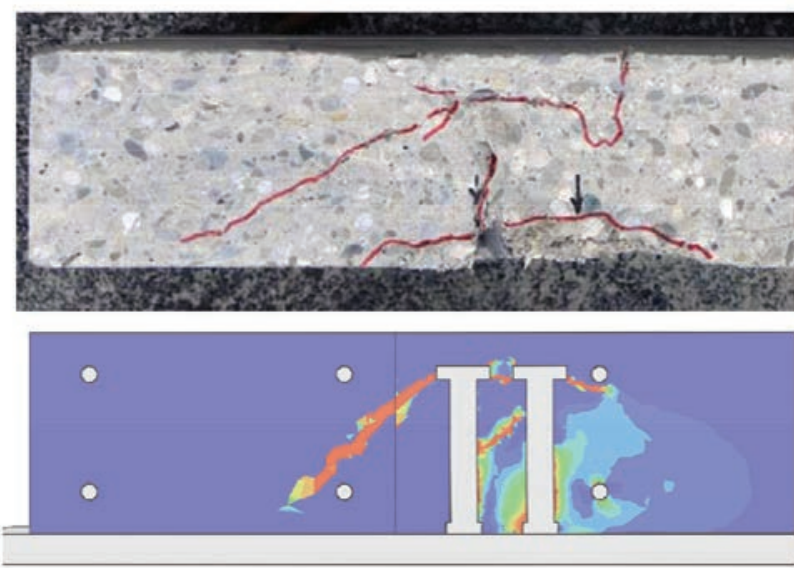

Figure 15. Initial crack in concrete slab

A characteristic crack emerges in the RC slab at higher values of tensile load in case of GR1 group, see Figure 15. As already mentioned, the group consisting of four headed studs, GR1, is characterized by the combined failure mode, which is marked by the emergence of an initial crack in concrete and by shear failure of headed studs.
The stress values in contact zone between the headed studs and concrete are by many times higher compared to compressive strength values for concrete. This is the result of the confined condition of stress in the concrete zone between the root and the head of the stud $[13,18]$. In order to sustain the confined condition of stress, the headed stud must have the necessary height to provide adequate anchoring. The minimum headed stud height of $4 d$ is specified in Eurocode, as a requirement for realizing the full shear strength. If the height of the headed stud is lower than $4 d$ but higher than $3 d$, the Eurocode defines a reduction coefficient for reducing the shear resistance of headed studs with regard to the concrete failure criterion. As long as the confined condition of stress in concrete can be maintained, the shear resistance of the grouped headed studs can be obtained by adding resistances of individual headed studs in the group. According to previously shown results, the tension force in the connection is higher when the headed studs are grouped. Adequate anchoring must be provided to maintain the confined condition in case of the group arrangement of headed studs. This is achieved by adopting greater height of headed studs. The height of the headed studs in the tested groups GR1 is $100 \mathrm{~mm}$, i.e. 6.25d, which is by 50 $\%$ greater than the $4 d$ prescribed by the Eurocode for the full strength of headed studs. The group GR1 is a boundary case, i.e. the crack in concrete opens at a shear load that is close to boundary values.

A parametric FEM study was performed so as to validate the previously described behaviour of grouped headed studs. A group of 9 headed studs, in $3 \times 3$ arrangement, $16 \mathrm{~mm}$ in diameter, was analysed. Headed studs $100 \mathrm{~mm}$ in height (6.25d) and $140 \mathrm{~mm}$ in height $(8.75 d)$ were studied. The results in form of load-slip diagrams are presented in Figure 16.

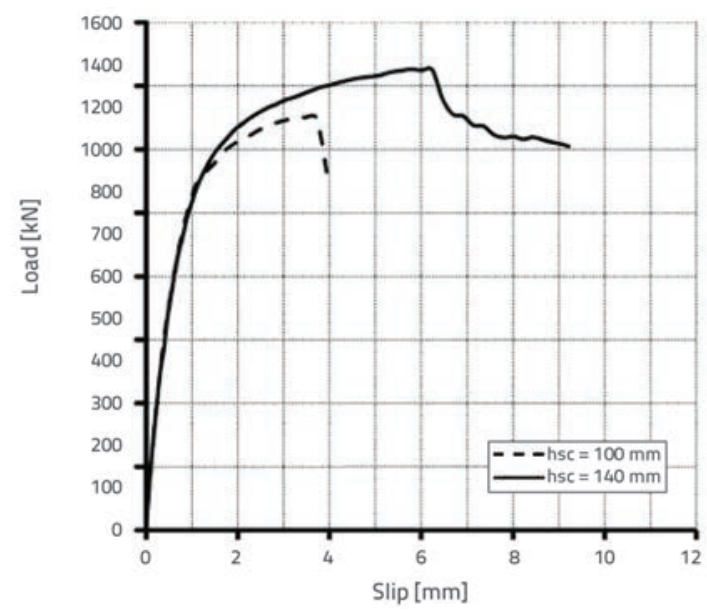

Figure 16. Load-slip curves, FEM results for $3 \times 3$ headed studs in group 
The structural design of longitudinal connections involving groups of headed studs implies that the studs are installed at the RC slab openings. To provide for production of prefabricate slabs with standard layout, the groups of headed studs must be spaced at equal intervals. The stud group ductility allows redistribution of the longitudinal shear force between the grouped headed studs in shear connection. Implementation of ductile headed studs is possible in full strength connections, as well in partial shear connections. Eurocode 4 has introduced the model of partial shear connection into the calculation. According to this model, the bending resistance of beams is determined from the shear resistance of the longitudinal shear connection. It is specified in Eurocode 4 that all headed studs ranging from 16 to $25 \mathrm{~mm}$ in diameter, with the height in excess of $4 d$, are classified as ductile headed studs. As shown in the paper, a group of four headed studs $16 \mathrm{~mm}$ in diameter can be considered ductile if the headed stud height exceeds 6.25d. The parametric analysis demonstrates that ductile behaviour of connection can be achieved with an adequate height of headed studs, see Figure 16. It is necessary to satisfy good anchoring conditions of headed studs in concrete slab by adopting higher height of studs in order to achieve the confined condition of concrete around the group of headed studs. The criteria defining when the behaviour of a headed stud group can be classified as ductile are presented in paper [7].

\section{REFERENCES}

[1] Okada, J., Yoda, T., Lebet, J.P.: The Study of the Grouped Arrangements of Stud Connectors on Shear Strength Behavior, Structural Eng./Earthquake Eng. SCE, 23 (2006) 1, pp. 75-89.

[2] Shim, C.S., Lee, P.G., Kim, D.W., Chung, C.H.: Effects of Group Arrangement on the Ultimate Strength of Stud Shear Connection, Proceedings of the 2008 Composite Construction in Steel and Concrete Conference VI, ASCE Conf. Proc., https://doi.org/10.1061/41142(396)8

[3] Dongyan, X., Yuqing, L., Zhen, Y., Jun, H.: Static behavior of multistud shear connectors for steel-concrete composite bridge, Journal of Constructional Steel Research, 74 (2012) pp. 1-7, https://doi.org/10.1016/j.jcsr.2011.09.017

[4] Guezouli, S., Lachal, A., Nguyen, Q.H.: Numerical investigation of internal force transfer mechanism in push-out tests, Engineering Structures, 52 (2013), pp. 140-152, https://doi.org/10.1016/j. engstruct.2013.02.021

[5] Chen, X., Kunitomo, S., Chong, W., Qingtian, S.: Parametrical static analysis on group studs with typical push-out tests, Journal of Constructional Steel Research, 72 (2012), pp. 84-96, https://doi. org/10.1016/j.jcsr.2011.10.029

[6] EN1994-2, Eurocode 4, "Design of Composite Steel and Concrete Structures. General Rules and Rules for Bridges", CEN (European Committee for Standardization), 2005.

[7] Spremic, M.: The analysis of headed studs group behavior in composite steel-concrete beam, PhD thesis, University of Belgrade, Faculty of Civil Engineering, 2013.

[8] EN1994-1-1, Eurocode 4, "Design of Composite Steel and Concrete Structures. General Rules end Rules for Buildings", CEN (European Committee for Standardization), December 2004

[9] EN1992-1-1, Eurocode 2, "Design of Concrete Structures, General Rules and Rules for Buildings", CEN (European Committee for Standardization), 2004.

\section{Conclusion}

Based on the results of experimental and numerical analyses conducted and presented in this paper, the following conclusions can be drawn:

- Ductility and shear resistance of shear connections are not disrupted by grouping the headed studs, if the spacing of headed studs in the group is in accordance with Eurocode 4.

- Behaviour, ductility and shear resistance of the connection realized with a group of headed studs depend on the height of headed studs in the group. When designing shear connections involving a group of headed studs, greater heights of headed studs should be used.

- Even if the distances between the headed studs are smaller than the prescribed minimum value of $5 d$, full shear resistance can be achieved by adopting the headed stud height in excess of $4 d$.

- By adopting the grouped headed studs height greater than $4 \mathrm{~d}$ the full shear resistance of headed studs can be achieved, even though their mutual distances are lower than the minimum prescribed value of $5 d$.

- No reduction of strength is required in case of groups of four headed studs in a $2 \times 2$ arrangement with the mutual distance of $3 d$ in the direction of the force, if the headed stud height exceeds $6.5 d$.

[10] Spremic, M., Markovic, Z., Veljkovic, M., Budjevac, D.: Pushout experiments off headed shear stud in group arrangement, Advanced Steel Construction, International Journal, 9 (2013) 2, pp. 170-191, https://doi.org/10.18057/IJASC.2013.9.2.4

[11] Krister Cederwall, L.A.: Push-out Tests on Studs in High Strength and Normal Strength Concrete, Journal of Constructional Steel Research, 36 (1996) 1, pp. 15-29.

[12] Spremic, M., Markovic, Z., Veljkovic, M., Pavlovic, M.: FE validation of equivalent diameter model for headed studs in group arrangement, Steel and Composite Structures 2017, Review in progress.

[13] Pavlovic, M., Markovic, Z., Veljkovic, M., Budjevac, D.: Bolted Shear Connectors vs. Headed Studs Behaviour in Push-out Tests, Journal of Constructional Steel Research, https://doi.org/10.1016/j.jcsr. 2013.05.003

[14] GB 50010-2002 Code for Design of Concrete Structures, National Standard of the People's Republic of China, China Architecture \& Building Press, Beijing 2002.

[15] ANSI/AISC 360-05, An American National Standard, Specification for Structural Steel Buildings, American Institute of Steel Construction, Chicago 2005.

[16] BS 5950-3.1:1990, "Structural Use of Steelwork in Building. Part 3 Design in Composite Construction", UK British Standard Institution, 1990

[17] Standard Specifications for Steel and Composite Structures, Japan Society of Civil Engineers, December, 2009

[18] Oehlers, D.J.: Stud shear connectors for composite beams, PhD Thesis, Department of Engineering University of Warwick, March 1980. 